\title{
Tight Junction Protein (Claudin-4) and Inflammatory Regulator (COX-2) Expression in Nasopharyngeal Carcinoma: An Immunohistochemical Study
}

\author{
RASHA M. ABDRABUH, M.D. and RANIA G. ROSHDY, M.D. \\ The Department of Pathology, Faculty of Medicine, Benha University
}

\begin{abstract}
Background: Claudin 4 is one of the tight junction proteins which considered one of the protective barriers that are mostly involved in the regulation of intercellular communication, paracellular transport and apical cell-to-cell adhesion. Overexpression of COX-2 and subsequent increase in prostaglandins (PGs) concentration have emerged in recent years as important players in cancer progression.
\end{abstract}

Aim of Study: To explore immunohisto chemically the expression of both claudin- 4 and COX2 in nasopharyngeal carcinoma and correlate their expression with each other and with different clinicopathological parameters.

Material and Methods: This retrospective study was done upon formalin fixed, paraffin blocks of 32 nasopharngeal carcinoma cases and 6 non-neoplastic nasopharyngeal epithelium. The materials were obtained from archieves of Pathology Departement and Early Cancer Detection Unit (ECDU), Faculty of Medicine, Benha University during the years 20122017. The immunohistochemical stain with Claudin 4 and COX2 was done and evaluated for each case.

Results: High expression of claudin 4 was observed in $44 \%$ of studied nasopharyngeal cases with statistically significant correlation with tumor stage and distant metastasis $(p<0.05)$. Positive expression of COX2 was detected in $75 \%$ of neoplastic group and statistically correlated with depth of tumor invasion, nodal invasion and tumor stage $(p<0.05)$. A statistically significant correlation was detected between overexpression of COX 2 and low expression of claudin 4 in the studied neoplastic cases $(p<0.05)$.

Conclusion: Claudin -4 has different tumorigenic effects besides their known adhesion attributes. Because of that, we believe that claudin 4 with other clinicopahological parameters may be a promising prognostic molecular indicator in nasopharyngeal cancer cases and can be taken as a novel biomarker for the predication of distant metastasis and survival. This work also highlights COX-2 expression's potential as an indicator of cancer progression that can contribute to assessment of prognosis and treatment decisions. Therefore, COX 2 inhibitors may have considerable potential as therapeutic agents.

Correspondence to: Dr. Rasha M. Abdrabuh, The Department of Pathology, Faculty of Medicine, Benha University
Key Words: Claudin-4 - COX2 - Nasopharyngeal carcinoma.

\section{Introduction}

NASOPHARYNGEAL carcinoma is a malignant epithelial neoplasm of the head and neck. Worldwide, it is uncommon tumor accounting about only $0.7 \%$ of all cancer [1]. Nasopharyngeal carcinoma is rare in united states and western Europe. But, it is relatively common in Southwest Asian, North Africa, and eskimo populations [2]. In Egypt, according to National Cancer Insitute, Cairo University, it represents bout $0.39 \%$ of all tumors and about $6.08 \%$ of respiratory tumors [3].

The most often used staging system to predict prognosis of nasopharyngeal carcinoma cases is American Joint Committee on Cancer (AJCC) TNM staging system. Although the patients can be classified owing to their clinical stage in this system, their outcome may vary significantly, making this staging system insufficient to perfectly predict the prognosis of this tumor [4]. So recognization of an accurate prognosticator is essential to improve the outcome of these patients.

Tight junctions (TJs) are specialized parts of cell-cell contact and have vital actions in preservation of cell polarity, cellular arrangement, adhesion, and paracellular permeability [5]. Recent studies have concluded that TJs not only have a vital roles on cell polarity but they also affect cell proliferation, invasion and distant metastasis [6].

One of these vital tight junctions is claudin protein family. This family is constituded of 27 known members. Each member has characteristic expression profile and barrier functions that differ interestingly from that of the other [7]. 
Claudin 4 (CLDN4) belongs to impermeability claudins. It has been described as a receptor for the cytotoxic clostridium perfringens endotoxin (CPE) [8].

Whereas some previous studies showed that the loss of claudin 4 expression has been involved in increased invasion and distant metastasis of tumors, others showed that its overexpression promote cancer progression [9].

There has been increasing evidence that inflammation and inflammatory microenvironment play an important role in the developement and prognosis of cancer. Several studies have shown that high levels of prostaglandins (PGs) have been detected in cancers of different anatomical sites, but the role of these metabolites in tumor growth and prognosis has been postulated [10].

Cyclooxygenases (COX) are well known enzymes that act as inflammatory regulators responsible for conversion of arachidonic acid to prostaglandin $\mathrm{H} 2$ (PGH2) [6]. COX has two isoforms: COX1 and COX2. The two isoforms have different functions as COX-1 is involved in maintaining homestasis and expressed by most normal cells while COX-2 is involved in many pathological events and abscent in most normal tissues [11] COX-2 appears to have a role in the neoplastic transformation and progression by affecting cell proliferation, cell adhesion, apoptosis, angiogenesis and immunesurvillance [12]

Whereas, some studies have shown that the levels of COX-2 increase when metastasis happens in nasopharyngeal carcinoma, others ones have failed to find any assocaition. A lso COX-2 prognostic values and roles of COX-2 inhibitors in clinical practice remain unclear.

This study aimed to investigate the expressions of both COX-2 and claudin- 4 and their relationship with clinicopathologic parameters of nasopharyngeal carcinoma that may represent a new chemotherapeutic agents for treatment of this malignant disease.

\section{Material and Methods}

This retrospective study included 6 cases of formalin-fixed, paraffin-embedded blocks of reactive nasopharyngeal tissue and 32 selected cases of nasopharyngeal carcinoma collected after approval of the Ethical Committee from the archieves of Pathology Department and Early Cancer Detection Unit (ECDU), Faculty of Medicine, Benha University and from international medical centre from the period between June 2012 and may 2017. To confirm diagnosis and grading; hematoxylin and eosin sections from each cases were reviewed by two pathologists. The grading of the studied cases were done accorging to WHO (2017) into type 1 (squamous cell carcinoma) and type 2 (undifferentiated carcinoma). Primary tumor size (T), lymph node metastasis $(\mathrm{N})$, and clinical staging were listed owing to the American Joint Committee on Cancer (AJCC) 8 th edition [13].

\section{Immunohistochemical staining:}

From each blocks, two formalin-fixed, paraffinembedded, 4-micron tissue sections on positively charged slides were prepared for each case. Immunohistochemical staining for both Claudin-4 and Cox-2 was performed (Table 1). Staining steps were done according to the standard $\mathrm{ABC}$ (avidinbiotin complex) procedures following the manufacturer"s insrtuctions (Neomarker, LABVISION, USA, CA 94538-7310). The sections were visualized with $0.02 \%$ diaminobenzidine (DAB) solution. Lastly the sections were counterstained with Mayer's hematoxlin then dehydrated in alcohols and mounted. Negative control was done by omitting the primary antibody.

Table (1): Studied antibodies in this research.

\begin{tabular}{|c|c|c|c|c|c|c|c|}
\hline Antibody & Source & Cat. No. & Clonality & $\begin{array}{l}\text { Antigen } \\
\text { retrieval }\end{array}$ & $\begin{array}{l}\text { Incubation } \\
\text { period }\end{array}$ & $\begin{array}{l}\text { Positive } \\
\text { control }\end{array}$ & $\begin{array}{l}\text { Staining } \\
\text { pattern }\end{array}$ \\
\hline $\begin{array}{l}\text { Claudin } 4 \\
\text { (ready to use) }\end{array}$ & Thermo fisher & $3 \mathrm{E} 2 \mathrm{C} 1$ & Monoclonal & $\begin{array}{l}\text { Citrate buffer } \\
\text { PH } 6.0\end{array}$ & $\begin{array}{l}\text { One hour at room } \\
\text { temperature }\end{array}$ & $\begin{array}{c}\text { Normal } \\
\text { colon }\end{array}$ & Membranous \\
\hline $\begin{array}{l}\text { Cox-2 } \\
\text { (ready to use) }\end{array}$ & $\begin{array}{l}\text { Labvision/ } \\
\text { thermoscientific, } \\
\text { Fremont, USA }\end{array}$ & RB-9072-R7 & Monoclonal & $\begin{array}{l}\text { Citrate buffer } \\
\text { PH } 6.0\end{array}$ & $\begin{array}{l}\text { One hour at room } \\
\text { temperature }\end{array}$ & $\begin{array}{l}\text { Colorectal } \\
\text { carcinoma }\end{array}$ & Cytoplasmic \\
\hline
\end{tabular}

\section{Immunohistochemical interpretation:}

The immunohistochemically stained sections were assesed under light microscope (leica). Clu- adin-4 postivity were cosidered only as brownish membranous staining and scored according to intensity of expression from $0-3$ where 0 is nega- 
tive, 1 is weakly positive, 2 is intermediately positive and 3 is stongly positive [14]. For statistical analysis; High claudin-4 was classified as neoplastic cells with staining intensity more than or equal 2 and low claudin-4 intensity with staining intensity less than 2 .

Cox-2 positivity was regarded as brown cytoplasmic staining. The postive results were classified into 0 (negative staining), 1 (less than $10 \%$ of the cells stained or weakly stained), 2 (10\%-50\% positively stained or moderate staining) and 3 (more than $50 \%$ of cells positively stained or strongly stained) [15]. To simplify the data analysis, cases were divided into positive group ( $>$ _ 2 ) and negative $(<2)$.

\section{Statistical analysis:}

Results were analyzed using SPSS (version 16) statistical package for Microsoft windows as follow: $p$-value $>0.05$ is non-significant (N) $p<0.05$ is significant (S) \& $p \leq 0.01$ is highly significant (HS).

\section{Results}

\section{A- Clinicopathological characters:}

- Group I: Non-neoplastic nasopharyngeal cases $(\mathrm{N}=6)$; this group includes reactive nasopharyngeal tissue adjacent the detected tumor.

- Group II: Neoplastic cases (N=32).

After histopathological examination the studied Nasopharyngeal carcinoma cases were divided into:

Type I: Squamous cell carcinoma $(\mathrm{N}=12)$ with well nest of pleomorphic squamous cells, hyperchromatic nuclei and squamous eddies, Type II: Undifferentiated carcinoma $(\mathrm{N}=20)$ with sheets of highly pleomorphic epithelial cells that showed syncytial growth pattern, vesicular nuclei with prominent central nucleoli, reactive lymphoid stroma and no keratinization.

After reviewing the demographic data, it was found that: pT1, pT2, Pt3 and pT4 were 3,6,15,8 cases respectively. For nodal status: NO, N1, N2 and $\mathrm{N} 3$ were 4, 710 and 11 cases respectively . From NPC cases 3 cases were of stage I, 7 of stage II, 12 cases of stage III and stage IV in 10 cases.

\section{B- Immunohistochemical claudin4 staining results:}

The expression of claudins 4 was found in $67 \%$ of group I (non neoplastic nasopharyngeal tissue) and in all of NPC studied cases in which $56 \%$ was of low score and high score in $44 \%$ of group II. (Figs. D\&F).
Correlation between clinicapathological parameters of the studied cases and expression of claudin 4:

There was a significant decrease in the expression of claudin 4 with the advancing of the stage, as $80 \% \& 75 \%$ of stage IV and II respectively showed low score of claudin 4 compared with only one of each stage I and II were of low score with percentage of $33 \%$ and $14.5 \%$ respectively ( $p$ value $<0.05$ ).

The distant metastasis was statistically correlated with low Claudin expression, as all cases (100\%) of M1 showed low Claudin score while only $19 \%$ of M 0 cases showed the same expression ( $p$-value <0.05).

There was no significant relationship determined between claudin 4 expression and histological type, tumor size and nodal status ( $p$-value $<0.05$ ) (Table 3).

\section{C-Immunohistochemical COX2 staining results:}

Positive COX2 expression was dominant in NPC in the form of diffuse brown cytoplasmic staining. It was detected in $24(75 \%)$ of carcinoma cases and detected only in 1 case of group I. This correlation was statistically significant $(p<0.05)$ Figs. (C\&E).

Regarding depth of invasion, COX 2 was positive in $33.3 \%, 50 \%, 80 \%$ and $88 \%$ of pT1, pT2, pT3, pT4 respectively; which was a statistically significant correlation $(p<0.05)$.

Out of 27 cases of NPC cases which were accompanied by nodal invasion, $78 \%$ were positive to COX2 expression, in which all of N3 (100\%) and $80 \%$ of $\mathrm{N} 2$ were positive, while only one of 4 cases with no nodal spread (25\%) showed positive immunostaining, so statistically significant correlationwas demonstrated with lymph node metastasis ( $p$-value <0.05).

The positivity of COX2 was increased in correlation to higher stage, so statistically significant correlation was demonstrated between its expression and tumor stage $(p$-value $<0.05)$ (Table 4$)$.

\section{$D$ - Correlation between Claudin-4 and COX2 expression:}

A statistically significant correlation was found between low expression of Claudin 4 and COX2 overexpression in the studied cases ( $p$-value $<0.05)$. Twenty four cases $(87.5 \%)$ examined in this study showed positive immunostaining for $\mathrm{COX} 2$; of them; $71 \%$ showed low claudin 4 expression in the time $87 \%$ of negative COX2 expressed cases showed high claudin 4 expression (Table 5). 
Table (2): Expression of COX 2 \& CLDN 4 in two-studied groups.

\begin{tabular}{|c|c|c|c|c|c|c|c|}
\hline \multirow{2}{*}{ Group } & \multirow{2}{*}{ No. } & \multicolumn{2}{|c|}{ Claudin 4} & \multirow{2}{*}{$p$-value } & \multicolumn{2}{|c|}{$\operatorname{Cox} 2$} & \multirow{2}{*}{$p$-value } \\
\hline & & Low & High & & Negative & Positive & \\
\hline Group I (non-neoplastic) & 6 & $2(33.5 \%)$ & $4(66.5 \%)$ & $>0.05$ & $5(83.5 \%)$ & $1(16.5 \%)$ & $<0.05$ \\
\hline Group II (neoplastic) & 32 & $18(56 \%)$ & $14(44 \%)$ & & $8(25 \%)$ & $24(75 \%)$ & \\
\hline
\end{tabular}

Table (3): Correlation between Claudin-4 expression and different clinico-pathologic features of the studied Neoplastic cases.
Table (4): Correlation between COX2 expression and different clinico-pathologic features of the studied NPC cases.

\begin{tabular}{|c|c|c|c|c|c|c|c|c|c|}
\hline \multirow{3}{*}{ Parameter } & \multirow{3}{*}{ Total } & \multicolumn{2}{|c|}{ CLDN4 expression } & \multirow{3}{*}{$\begin{array}{c}p- \\
\text { value }\end{array}$} & \multirow{3}{*}{ Parameter } & \multirow{3}{*}{ Total } & \multirow{2}{*}{\multicolumn{2}{|c|}{$\begin{array}{c}\text { COX2 expression } \\
\text { in NPC }\end{array}$}} & \multirow{3}{*}{$\begin{array}{c}p- \\
\text { value }\end{array}$} \\
\hline & & \multirow{2}{*}{$\begin{array}{c}\text { Low } \\
(\mathrm{N}=18) \\
\end{array}$} & \multirow{2}{*}{$\begin{array}{c}\text { High } \\
(\mathrm{N}=14)\end{array}$} & & & & & & \\
\hline & & & & & & & $\begin{array}{c}\text { Negative } \\
(\mathrm{N}=18)\end{array}$ & $\begin{array}{l}\text { Positive } \\
(\mathrm{N}=24)\end{array}$ & \\
\hline \multicolumn{10}{|c|}{$(\mathrm{N}=18) \quad(\mathrm{N}=24)$} \\
\hline $\begin{array}{l}\text { Well differentiated } \\
\text { type I }\end{array}$ & 14 & $10(50 \%)$ & $4 \quad(50 \%)$ & $>0.05$ & $\begin{array}{l}\text { Tyре: } \\
\text { Well differentiated }\end{array}$ & 14 & $6(36 \%)$ & $8 \quad(64 \%)$ & $>0.05$ \\
\hline $\begin{array}{l}\text { Undifferentiated } \\
\text { carcinoma type III }\end{array}$ & 18 & $8 \quad(44.5 \%)$ & $10(55.5 \%)$ & & $\begin{array}{l}\text { type I } \\
\text { Undifferentiated } \\
\text { carcinoma type III }\end{array}$ & 18 & $3(17 \%)$ & $13(83 \%)$ & \\
\hline $\begin{array}{l}\text { Primary tumor } \\
\text { extension: }\end{array}$ & & & & & $\begin{array}{l}\text { Primary tumor } \\
\text { extension: }\end{array}$ & & & & \\
\hline $\mathrm{T} 1$ & 3 & $2(66.5 \%)$ & $1 \quad(33.5 \%)$ & \multirow[t]{4}{*}{$>0.05$} & $\mathrm{~T} 1$ & 3 & $2(66.5 \%)$ & $1 \quad(33.5 \%)$ & $<0.05$ \\
\hline $\mathrm{T} 2$ & 6 & $4 \quad(66.5 \%)$ & $2 \quad(33.5 \%)$ & & $\mathrm{T} 2$ & 6 & $3(50 \%)$ & $3(50 \%)$ & \\
\hline T3 & 15 & $8 \quad(53 \%)$ & $7 \quad(47 \%)$ & & $\mathrm{T} 3$ & 15 & $2(20 \%)$ & $12(80 \%)$ & \\
\hline $\mathrm{T} 4$ & 8 & $4 \quad(50 \%)$ & $4 \quad(50 \%)$ & & $\mathrm{T} 4$ & 8 & $2(12 \%)$ & $6 \quad(88 \%)$ & \\
\hline \multicolumn{5}{|l|}{ Nodal status: } & Nodal status: & & & & \\
\hline N0 & 4 & $1 \quad(25 \%)$ & $3(75 \%)$ & \multirow[t]{4}{*}{$>0.05$} & N0 & 4 & $3(75 \%)$ & $1 \quad(25 \%)$ & $<0.05$ \\
\hline N1 & 7 & $4 \quad(57 \%)$ & $3(43 \%)$ & & $\mathrm{N} 1$ & 7 & $3(42.5 \%)$ & $4 \quad(47.5 \%)$ & \\
\hline $\mathrm{N} 2$ & 10 & $7 \quad(70 \%)$ & $3(30 \%)$ & & $\mathrm{N} 2$ & 10 & $3(30 \%)$ & $7 \quad(70 \%)$ & \\
\hline N3 & 11 & $6 \quad(54.5 \%)$ & $5 \quad(45.5 \%)$ & & N3 & 11 & $0(0 \%)$ & $11(100 \%)$ & \\
\hline \multicolumn{5}{|l|}{ Distant metastasis: } & \multicolumn{5}{|l|}{ Distant metastasis: } \\
\hline M0 & 22 & $8 \quad(36 \%)$ & $14(64 \%)$ & \multirow[t]{2}{*}{$<0.05$} & M0 & 22 & $8(36 \%)$ & $14(64 \%)$ & $>0.05$ \\
\hline M1 & 10 & $10(100 \%)$ & $0 \quad(0 \%)$ & & M1 & 10 & $0(0 \%)$ & $10(100 \%)$ & \\
\hline \multicolumn{5}{|l|}{ Stage: } & \multicolumn{5}{|l|}{ Stage: } \\
\hline I & 3 & $1 \quad(33.5 \%)$ & $2 \quad(66.5 \%)$ & $<0.05$ & I & 3 & $2(66.5 \%)$ & $1 \quad(33.3 \%)$ & $<0.05$ \\
\hline II & 7 & $3 \quad(43 \%)$ & $4 \quad(57 \%)$ & & II & 7 & $3(43 \%)$ & $3 \quad(57 \%)$ & \\
\hline III & 12 & $9 \quad(75 \%)$ & $3 \quad(25 \%$ & & III & 12 & $2(17 \%)$ & $10(83 \%)$ & \\
\hline IV & 10 & $8 \quad(80 \%)$ & $2(20 \%)$ & & IV & 10 & $1(10 \%)$ & $9(90 \%)$ & \\
\hline
\end{tabular}

Table (5): Correlation between COX2 expression and Claudin- 4 in NPC cases.

\begin{tabular}{cccc}
\hline \multirow{2}{*}{ Cox 2 expression } & \multicolumn{2}{c}{ Claudin 4 expression } & \multirow{2}{c}{$\begin{array}{c}p^{-} \\
\text {value }\end{array}$} \\
\cline { 2 - 3 } & Low & High & \\
\hline Negative (8 cases) & $1(12.5 \%)$ & $7(87.5 \%)$ & $<0.05$ \\
Positive (24 cases) & $17(71 \%)$ & $7(29 \%)$ & \\
\hline
\end{tabular}



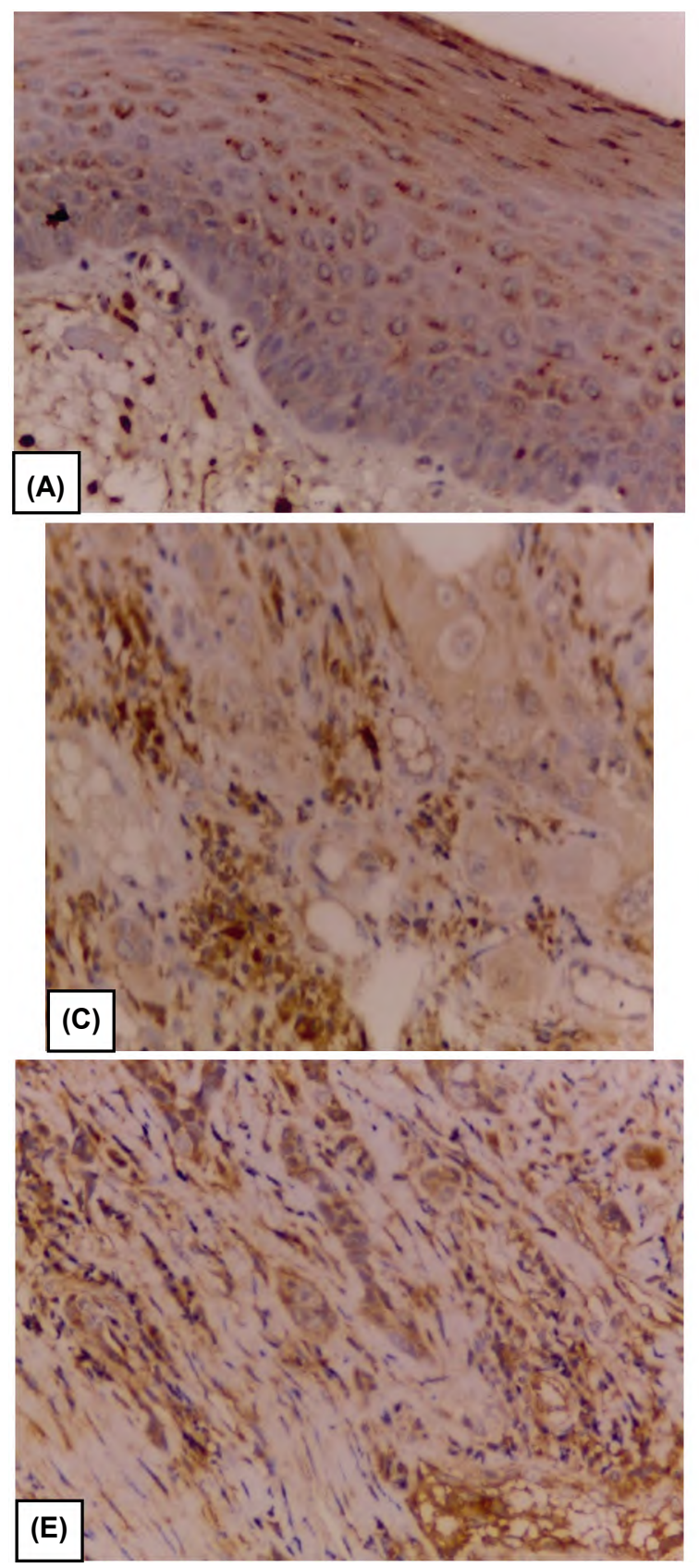
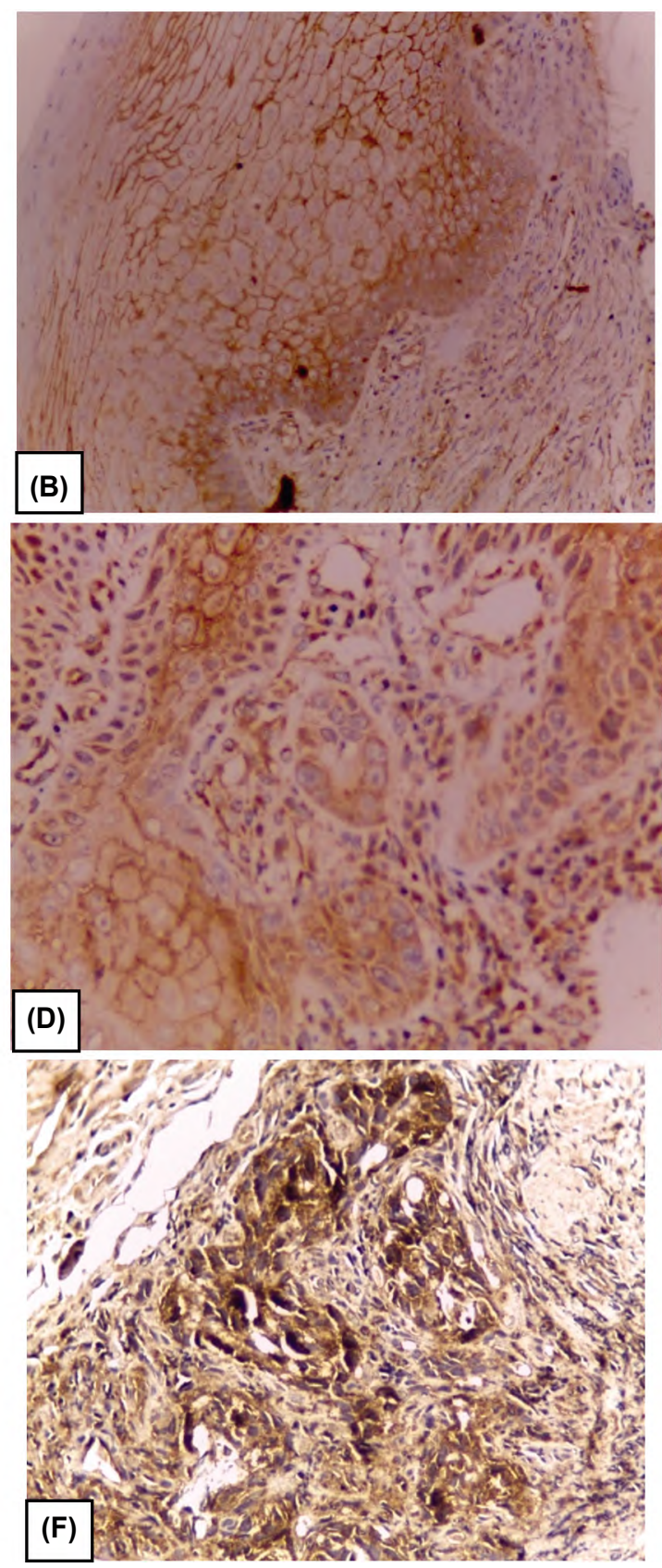

(F)

Fig.: (A): Negative cytoplasmic COX2 expression in normal squamous epithelium. (B): High membranous claudin 4 expression in normal squamous epithelium. (C): Positive weak cytoplasmic expression of COX2 in TypeI nasopharyngeal carcinoma. (D): Low membranous claudin 4 expression in Type I nasopharyngeal carcinoma. (E): Positive strong cytoplasmic expression of COX2 in Type II nasopharyngeal carcinoma. (F): Low membranous expression of Claudin 4 in TypeII nasopharyngeal carcinoma.

\section{Discussion}

In certain geographic and ethnic populations, nasopharyngeal carcinoma (NPC) registers high incidence rates, that still lacks relevant biomarkers for its development and prognosis; therefore, studying more biomarkers are going to predict of the prognosis of (NPC) andestablishment of targeted therapeutic approaches [18]

Claudin 4 is overexpressed in many cancer types including pancreatic ductal adenocarcinoma, endometrial adenocarcinoma, ovarian, urinary bladder, and breast cancers [19]. Whileits expression islost in other different types of cancer such as in hepatocellular carcinoma, renal cell carcinomas and squamous cell carcinoma [20].

Thirty two cases of (NPC) with different stages and grades were included in this retrospective work and studied immunohistochemically for claudin 4 and $\mathrm{COX} 2$.

Only one case of the studied NPC was of negative claudin 4 expression that was included within 
low claudin 4 scoring groupand all the remaining cases showed positive claudin 4 expression. Similarly, claudin 4 was detected in all cases in which claudin 4 was studied in 18 patients with EBVrelated non-keratinized NFC [21].

Claudin 4 overexpression was scored in 14 cases $(44 \%)$ of studied NPC, in contraste in the study done by Hsueh, et al., [22] ; 88\% of studied cases scored high claudin 4 expression. This difference may be due to low numbers of our studied cases comparing with 176 cases in Hsueh'swork.

Concerning the expression in normal tissue, this work showed expression ofclaudin 4 in $66.5 \%$ cases of non neoplastic group. This matches with Hsueh, et al., [22] who demonstrated claudin 4 expression in $57.9 \%$ of the non-neoplastic cases.

This finding also is proven in other normal tissue like Soini, et al., [23] who detected that Claudin 4 was expressed in normal human bronchi, bronchioles and in type 2 alveolar cells while type 1 alveolar cells were negative.

When correlating claudin 4 expression with the stage of studied NPC cases, an inverse statistically significant correlation was found as $75 \%$ \& $80 \%$ of stage III\&IV respectively were of low claudin 4 score comparing to $14.5 \%$ of stage II and $33 \%$ of stage I showed same low score.

The same finding was registered when correlating with distant metastasis as, all cases of M 1 $(100 \%)$ were included within low claudin 4 expression group.

In keeping with current study, Suren, et al., [24] who found statistically significant correlation between low claudin 4 expressions and stage of NPC. Similar results were in Hsueh, et al., [22] study in which decreased claudin 4 immunostaining was statistically related to advanced stage and distant metastasis.

Our results also proven the study of Ohtani [25] in which claudin 4 expression was significantly decreased with advanced stage and peritoneal metastasis of gastric carcinoma.

Analysis of claudin4 expression and clinicopathological parameters of colorectal carcinoma in Tani, et al (26) study showed that claudin-4 levels were inversely correlated with depth of tumor invasion which was similarly shown in our studied cases of NPC but without registered significant difference.
Assessment of correlation with other parameters including tumor size and nodal invasion was insignificant, similar results were seen in the study of Suren, et al., [24] also, no significant relation with the same parameters of NPC.

In study of breast cancer cases, most high grades and node positive cases in Al Zakaria, et al., [27] were all of claudin 4 high expression in the contrast of our findings, however, none of these parameters reached statistically significant relation.

Our claudin 4 expression results regarding the staging and distant metastasis are actually the same with gastric carcinoma and hepatocellular carcinoma [25], but it was the opposite comparing with that in breast, ovarian and colorectal carcinoma [28] . It may be due to the different signaling pathways could interfere with post-translational modification of the expressed claudin 4. Also Differences in the underlying mechanism of carcinogenesis of each entity of carcinoma. These could explain this controversy.

The differential regulation of claudin proteins in various cancer types represents an opportunity to determine the mechanism of different therapeutic responses [25].

Regarding COX2, the association between COX-2 expression and various types of cancers has been cleared in recent studies. While some studies have detected the prognostic value of Cox2 in NPC, others fail to find the same value. Both of the diagnostic and prognostic values of the COX-2 in NPC and the role of COX-2 inhibitors in treatment remain unclear [29]. In this current work, a clear association of COX-2 expression with clinico-pathological parameters of NPC was demonstrated.

When correlating COX2 with tumor extension, nodal metastasis and the tumor stage, we observed astatistically significant correlation between COX2 expression and all of them $(p<0.05)$. Despite all of M1 showed positive COX2 but we cannot registered significant difference with COX2 positive cases within M0 group.

This data also supports results of Weigi et al., [30] and Honghai, et al., [31] who have reported that COX2 overexpression was significantly associated with nodal metastasis as COX2 overexpression was detected in $95 \%$, and $84.5 \%$ respectively of nodal metastatic cases in the same work done by Weiqi, $92 \%$ of advanced stage registered high COX 2 expression with statistically significant correlation. 
Also Yang, et al., [32] determined results that are consistent with what our work found of statistically significant correlation with the stage and, tumor size.

Shi, et al., [33] reached the same significant correlation with stage as $83 \%$ of advanced cases and $89 \%$ of M1 were with high COX2. Parallel to our results concerning distant metastasis, he found that most cases of M1 showed COX 2 overexpression but without statistically significant correlation like this present result. Also the study by Honghai, et al., [31] which failed to establish any correlation between COX2 overexpression and metastasis.

In contrast to these results, the studies of Yafeng, et al., [34] and Shanzhi, et al., [35] found no statistically correlation between COX 2 and tumor size and stage $(p>0.05)$. It may be due to variations in technique, number of studied cases and standards for identifying COX-2 positivity.

In attempt to view the inverse relationship between claudin- 4 and COX 2 expression, it can be explained by that COX2, as known, PGDs synthesizer which by its role causes a significant decrease of the tight junction proteins, of which is claudin-4 leading to alteration in cell-cell adhesion. It is also proven by that NSAIDs and other drugs having chemo-preventive effects by increasing the intracellular $\mathrm{Ca} 2+$ concentration that result in induced claudin-4 levels. So, The loss of tight junction proteins and permeability control of bothepithelial and endothelial membrane by increased COX2, it will promote cell invasiveness, motility and proliferation.

\section{Conclusion:}

This work highlights the association between COX-2 expression and progression of NPC so, it can be considered as an indicator of cancer progression and help in the assessment of prognosis and treatment plan. Therefore, COX-2 inhibitors may have valuable use as therapeutic agents. Also in this study, the significant relationship between the decline in claudin 4 expression with both the stageand distant metastasis of tumor may indicate that, claudins 4 has different tumorigenic effects besides their known adhesion attributes. Because of that, claudin 4 can be taken as a novel biomarker for the predication of distant metastasis and survival [36].

\section{Conflict of interest:}

No conflict of interest in this work.

\section{References}

1- SABARIMURUGAN S., KUMARASAMY C., BAXI S., et al.: Systematic review and meta-analysis of prognostic microRNA biomarkers for survival outcome in nasopharyngeal carcinoma. PLoS One, 14 (2), 2019.

2- FERLAY J., SOERJOMATARAM I., DIKSHIT R., et al.: Cancer incidence and mortality worldwide: Sources, methods and major patterns in GLOBOCAN 2012. Int. J. Cancer, 136 (5): E359-386, 2015.

3- MOKHTAR N., SALAMA A., BADAWAY O., et al.: Cancer Pathology Registry A 12 year registry 2000-2011. Pathology Dept., NCI, 67-71, 2016.

4- MAHDAVIFAR N., GHONCHEH M., MOHAMMADIAN-HAFSHEJANI A., et al.: Epidemiology and Inequality in the Incidence and Mortality of Nasopharynx Cancer in Asia. Osong Public Health Res. Perspect, 7 (6): 360372, 2016

5- KRAUSE G., WINKLER L., MUELLER S.L., et al.: Structure and function of claudins. Biochim. Biophys. Acta., 1778: 631-645, 2008.

6- WATARI A., KODAKA M. and MATSUHISA K.: Identification of claudin- 4 binder that attenuates tight junction barrier function by TR. Scientific Reports, Vol. 7, Article Number: 14514, 2017.

7- AJAZ A. BHATI, SRIJAYAPRAKASH UPPADA, et al. Junction proteins and signaling pathways in cancer and and inflammation. Front. Physiol., Vol. 9: 1942, 2019.

8- LI X., IIDA M., TADA M., et al.: Development of an anti-claudin-3 and -4 bispecific monoclonal antibody for cancer diagnosis and therapy. J. harmacol. Exp. Ther., Vol. 351: 206-21, 2014.

9- OLIVEIRA S. and MORGADO-DIAZ J.: Claudins: Multifunctional players in epithelial tight junctions and their role in cancer. Cell Mol. Life Sci., 64: 17-28, 2007.

10- YI C., WANG Y., ZHANG C., et al.: Cleavage and polyadenylation specific factor 4 targets NF-kappaB / cyclooxygenase-2 signaling to promote lung cancer growth and progression. Cancer Letters, 381 (1): 1-13, 2016.

11- SHAOYAN X., QIULIANG W., YONGSHENG Z., et al.: Clinical Value of COX-2, EFGR and Ki-67 expression in Nasopharyngeal Carcinoma. Guangdong Medical Journal, 10: 1422-5, 2012.

12- SUNITA B.S., SEN A. and SUHAG V.: To evaluate immunoreactivity of cyclooxygenase- 2 in cases of endometrial carcinoma and correlate it with expression of p53 and vascular endothelial growth factor. Journal of Cancer Research and Therapeutics, Vol. 14 (6), 2018.

13- GAO F., ZAFAR M., JÜTTNER S., et al.: Expression and Molecular Regulation of the Cox 2 Gene in Gastroenteropancreatic Neuroendocrine Tumors and Antiproliferation of Nonsteroidal Anti-Inflammatory Drugs (NSAIDs) Med. Sci. Monit., 24: 8125-8140, 2018.

14- EDWARD B. STELOW and BRUCE M. WENIG: Update from The 4th Edition of the World Health Organization Classification of Head and Neck Tumours: Nasopharynx, Head Neck Pathol. Mar., 11 (1): 16-22, 2017.

15- LEE A.W.M., LYDIATT W.M., COLEVAS A.D., et al.: Nasopharynx. In: Amin M.B. (Ed), AJCC Cancer Staging Manual, $8^{\text {th }}$, New York: Springer, p. 103, 2017. 
16- ZHANG X., WANG H., LI Q., et al.: Differences in the expression profiles of claudin proteins in human nasopharyngeal carcinoma compared with non-neoplastic mucosa Diagn. Pathol., 13: 11, 2018.

17- CHRESTELLA J., FARHAT F., DAULAY E.R., et al.: Cyclooxygenase-2 Expression and its Correlation with Primary Tumor Size and Lymph Node Involvement in Nasopharyngeal Carcinoma.Open Access Maced J. Med. Sci. ,Nov. 25; 6 (11), 2018.

18- LIU J., TANG G. and HUANG H.: Expression level of NUAK1 in human nasopharyngeal carcinoma and its prognostic significance. Eur. Arch. Otorhinolaryngol., Oct., 275 (10): 2563-2573, 2018.

19- RANGEL L.B.A., AGARWAL R., D'SOUZA T., et al.: Tight junction proteins claudin- 3 and claudin- 4 are frequently overexpressed in ovarian cancer but not in ovarian cystadenomas. Clin. Cancer Res., 9: 2567-2575, 2003.

20- MORITA K., TSUKITA S. and MIYACHI Y.: Tight junction-associated proteins (occludin, ZO-1, claudin-1, claudin-4) in squamous cell carcinoma and Bowen's disease. Br. J. Dermatol., 151: 328-334, 2004.

21- KOJIMA F., ISHIDA M., TAKIKITA M., et al.: Claudin expression profiles in Epstein-Barr virus associated nasopharyngeal carcinoma Oncology Reports, 23: 927-931, 927, 2010.

22- HSUEH C., CHANG Y.S., TSENG N.M., et al.: Expression pattern and prognostic significance of claudins 1,4 , and 7 in nasopharyngeal carcinoma. Hum. Pathol., 41: 944950, 2010

23- SOINI Y.: Claudins in lung diseases, Respir Res., 12 (1): 70, 2011.

24- SUREN D., YILDIRIM M., KAYA V., et al.: Expression patterns of claudins 1,4 , and 7 and their prognostic significance in nasopharyngeal carcinoma. JBUON, 20 (1): 212-217, 2015.

25- OHTANI S., TERASHIMA M., SATOH J., et al.: Expression of tight-junction-associated proteins in human gastric cancer: Downregulation of claudin- 4 correlates with tumor aggressiveness and survival Gastric Cancer, Vol. 12, Issue 1, pp 43-51, 2009.

26- TANI F.R., SASAKI T., YI LUO, et al.: Anti-claudin-4 extracellular domain antibody enhances the antitumoral effects of chemotherapeutic and antibody drugs in color- ectal cancer. Oncotarget., Dec. 21; 9 (100): 37367-37378, 2018.

27- ALSHIMAA ZAKARIA, NAGLAA ELKINAL, IMAN LOAY, et al.: Immunohistochemical Characterization and Subclassification of Triple Negative Breast Cancer of Egyptian Female Patients. Medical Journal of Cairo University, Vol. 86, No. 5, p. 2533-2541, 2018.

28- MICHL P., BARTH C., BUCHHOLZ M., et al.: Claudin4 expression decreases invasiveness and metastatic potential of pancreatic cancer. Cancer Res., 63: 6265-6271. $21,2003$.

29- LU S.C., ZHONG J.H., TAN J.T., et al.: Association between COX-2 gene polymorphisms and risk of hepatocellular carcinoma development: A meta-analysis. BMJ Open, 5 (10), 2015.

30- WEIQI B., BAOHUA H., JIANGUO T., et al.: COX-2 and EGFR Expression in Nasopharyngeal Carcinoma and their Relationship. Zhejiang Practical Mdeicine, 03, 2012.

31- HONGHAI Z. and XIAOYUAN Z.: Relationship between cyclooxygenase 2 and cervical lymph node metastasis of nasopharyngeal carcinoma: Chinese Journal of Medicine, 94 (18): 1409-1412, 2014.

32- YANG G., DENG Q., FAN W., et al.: Cyclooxygenase2 expression is positively associated with lymph node metastasis in nasopharyngeal carcinoma. PLoS One, 12 (3), 2017.

33- SHI D., XIAO X., TIAN Y., et al.: Activating enhancerbinding protein-2alpha induces cyclooxygenase-2 expression and promotes nasopharyngeal carcinoma growth. Oncotarget, 6 (7): 5005-21, 2015.

34- XINHUA X., GUOQING H., SONG L., et al.: Expression of Cyclooxygenase-2 in Nasopharyngeal Carcinoma and Its Relation to Angiogenesis and Prognosis .The ChineseGerman Journal of Clinical Oncology, 02, 2006.

35- LI Z.L., YE S.B., YANG L.Y., et al.: COX-2 promotes metastasis in nasopharyngeal carcinoma by mediating interactions between cancer cells and myeloid-derived suppressor cells. Oncoimmunology. Jul., 4 (11): e1044712, 2015.

36- MIMA S., TSUTSUMI S., USHIJIMA H., et al.: Induction of Claudin- 4 by Nonsteroidal Anti-inflammatory Drugs and its Contribution to their Chemopreventive Effect. Cancer Research, 65 (5): 1868-76, 2005. 


\section{ظهور بروتينات الوصلة الضيقة (كلودين \& ) ومنظم الالتهاب (كوكس Y) )

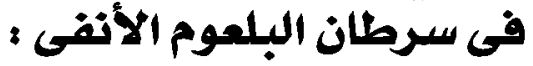 دراسة مناعية هستوكيميائية البانية}

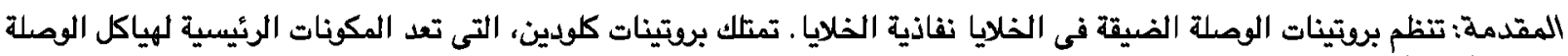

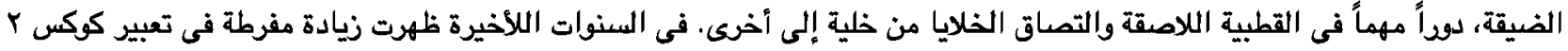
وما تلاه من زيادة فى تركيز البروستاجلاندين بوصفهما لاعبين مهمين فى تطود السرطان العان.

الهدف من البحث: هو الكشف بطريقة مناعية هستوكيميائية عن ظهود كل من كلودين ع وكوكس ب في أودام البلعوم الأنفى الغبيثة ومقارنة النتائج مع بيانات المرضى الباثولوجية والأكلينيكية.

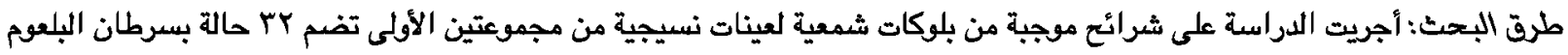

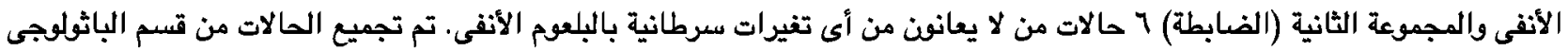

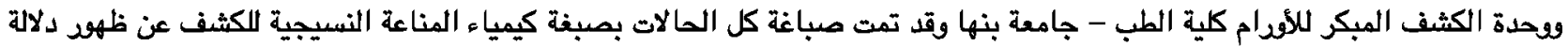

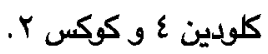

نتائج البحث:ظهرت الدلالة كلودين ع فى عع٪ من حالات سرطان البلعوم الأنفى المدروسة والتى كان لها دلالة إحصائية مع مرحلة الودم

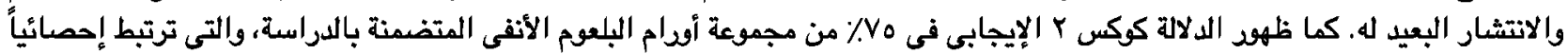

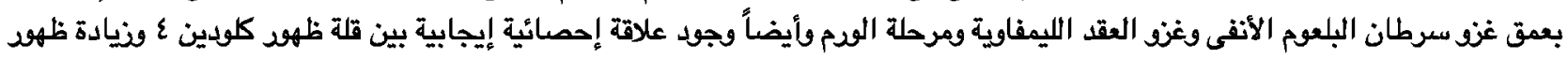
كوكس r.

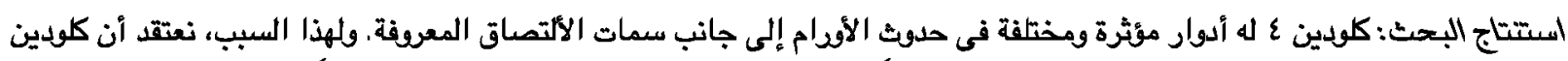

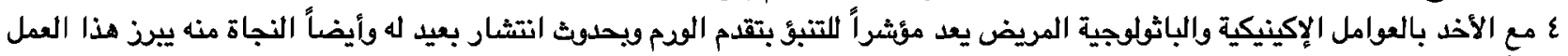

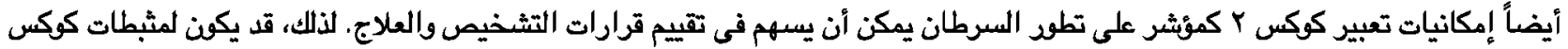
ب إمكانيات كبيرة كعوامل علاجية. 